\title{
HUBUNGAN PENGETAHUAN DAN SIKAP TERHADAP PERILAKU CUCI TANGAN PADA MASYARAKAT KELURAHAN PEGIRIAN
}

\author{
RELATIONSHIP BETWEEN KNOWLEDGE AND ATTITUDE TO HAND \\ WASHING BEHAVIOR IN KELURAHAN PEGIRIAN
}

\section{Audria Octa Anggraini Widi Lestari}

Departemen Promosi Kesehatan dan Ilmu Perilaku Fakultas Kesehatan Masyarakat, Universitas Airlangga, Surabaya

E-mail: audria.octa@yahoo.com

\begin{abstract}
Background: Implementing clean and healthy living behaviors is useful to prevent, cope and protect against disease threats and utilize quality health services, effective and efficient. Hand washing with soap is an indicator of clean and healthy living behavior. Washing hands with soap can prevent various diseases. One of them is diarrhea. The fingers can be the pathway for pathogens, bacteria or viruses that can cause diarrhea. Therefore, hand washing becomes one of effective and efficient prevention efforts to avoid the occurrence of disease. Purpose: This research has a purpose to know the relationship between knowledge and attitude towards hand washing action in RW III Pegirian Village Semampir District Surabaya. Methods: This research used descriptive method with Simple Random Sampling technique, samples of 84 respondents. The independent variables in this study consisted of knowledge of handwashing and attitude towards hand washing. The dependent variable in this research is hand washing action. The collected data were analyzed using spearman correlation test with the aim of knowing the relationship and strong relationship of research subjects. Results: The result of this research is the correlation between knowledge with hand washing with $p$ value 0.009 with strong correlation with correlation coefficient 0.282 . And there is a relationship between attitude to hand washing with hand washing result $p$ value 0.017 and strong relationship is strong with correlation coefficient 0.271 . Conclusion: There is a relationship between knowledge and attitudes with the act of hands washing and strong relationships are strong.
\end{abstract}

Keywords: knowledge, attitude, action, hand wash

\begin{abstract}
ABSTRAK
Latar Belakang: Melaksanakan perilaku hidup bersih dan sehat bermanfaat untuk mencegah, menanggulangi dan melindungi diri dari ancaman penyakit serta memanfaatkan pelayanan kesehatan yang bermutu, efektif dan efisien. Cuci tangan dengan sabun merupakan salah satu indikator perilaku hidup bersih dan sehat. Mencuci tangan menggunakan sabun dapat mencegah berbagai penyakit, salah satunya adalah diare. Jari tangan dapat menjadi jalur masuk bagi patogen, bakteri atau virus yang bisa menyebabkan diare, oleh karena itu mencuci tangan menjadi salah satu upaya pencegahan yang efektif dan efisien untuk menghindari terjadinya penyakit. Tujuan: Penelitian ini mempunyai tujuan mengetahui hubungan antara pengetahuan dan sikap terhadap tindakan cuci tangan di RW III Kelurahan Pegirian Kecamatan Semampir Surabaya. Metode: Penelitian ini menggunakan metode deskriptif dengan teknik Simple Random Sampling, sampel sebanyak 84 responden. Variabel bebas dalam penelitian ini terdiri dari pengetahuan tentang cuci tangan dan sikap terhadap cuci tangan. Variabel terikat dalam penelitian ini adalah tindakan cuci tangan. Data yang terkumpul dianalisis menggunakan uji korelasi spearman dengan tujuan mengetahui hubungan dan kuat hubungan subjek penelitian. Hasil: Penelitian ini menunjukkan adanya hubungan antara pengetahuan dengan tindakan cuci tangan yaitu dengan hasil $p$ value sebesar 0,009 dan kuat hubungan
\end{abstract}


bersifat kuat dengan koefisien korelasi sebesar 0,282. Terdapat hubungan antara sikap dengan tindakan cuci tangan yaitu dengan hasil $p$ value sebesar 0,017 dan kuat hubungan bersifat kuat dengan koefisien korelasi 0,271. Kesimpulan: Terdapat hubungan antara pengetahuan dan sikap dengan tindakan cuci tangan dan kuat hubungan bersifat kuat.

Kata Kunci: pengetahuan, sikap, tindakan, cuci tangan

\section{PENDAHULUAN}

Saat ini, Perilaku Hidup Bersih dan Sehat (PHBS) masih menjadi permasalahan kesehatan masyarakat. Perilaku yang belum bersih dan sehat menyebabkan munculnya penyakit yang menjadi permasalahan kesehatan masyarakat. Diare adalah salah satu penyakit yang paling banyak disebabkan karena faktor kebersihan perorangan yang belum bersih dan sehat. Diare merupakan kondisi seseorang yang mengalami gangguan dalam buang air besar, sehingga konsistensinya lembek bahkan cair dan buang air besar lebih sering yaitu empat kali atau lebih (Widjaja, 2002).

Perilaku cuci tangan yang benar merupakan salah satu aspek yang menjadi indikator dalam PHBS yang saat ini menjadi perhatian dunia. Hal ini disebabkan tidak hanya di Negara berkembang, namun juga di Negara maju, masih banyak masyarakat yang lupa melakukan perilaku cuci tangan yang benar. Hal ini menunjukkan masih kurangnya praktek atau tindakan mencuci tangan di masyarakat (Anggraini, 2010).

Penelitian WHO menunjukkan bahwa kejadian diare dapat berkurang sampai 45\% karena perilaku mencuci tangan menggunakan sabun dengan benar. Penelitian yang dilakukan oleh Burton, dkk (2011) menunjukkan bahwa kuman pada tangan akan lebih mudah berpindah apabila mencuci tangan menggunakan sabun dibandingkan bila mencuci tangan hanya menggunakan air saja, sehingga penyakit diare dapat dicegah dengan perilaku cuci tangan yang benar dan menggunakan sabun dalam pelaksanaannya serta dengan langkah-langkah mencuci tangan yang lengkap.

Menurut target cakupan pelayanan penderita diare yang datang ke sarana kesehatan dan kader kesehatan adalah $10 \%$ dari perkiraan jumlah penderita diare. Insidensi diare nasional hasil Survei Morbiditas Diare tahun 2014 yaitu sebesar 270/1.000 penduduk, maka diperkirakan jumlah penderita diare di fasilitas kesehatan pada tahun 2016 sebanyak 6.897.463 orang, sedangkan jumlah penderita diare yang dilaporkan ditangani di fasilitas kesehatan adalah sebanyak 3.198.411 orang atau 46,4\% dari target, (Kemenkes, 2017).

Provinsi Jawa Timur menempati posisi tertinggi kedua pada kasus diare. Perkiraan penemuan kasus diare di fasilitas kesehatan menurut provinsi tahun 2016 di Jawa Timur yaitu sejumlah 1.048.885 kasus (Kemenkes, 2017). Berdasarkan data dari Dinas Kesehatan Provinsi Jawa Timur (2015), Surabaya menempati posisi tertinggi kedua Kabupaten/Kota yang menangani kasus diare di Jawa Timur setelah Kabupaten Pamekasan.

Jumlah kasus diare yang ditangani oleh Kota Surabaya pada tahun 2014 sejumlah 86,893 kasus dengan persentase penanganan kasus sebesar $143 \%$ dari target penanganan kasus. Persentase penanganan kasus diare di wilayah Surabaya lebih tinggi dari persentase total di Jawa Timur yaitu sebesar $127 \%$. Berdasarkan data terbaru, yaitu pada tahun 2015, Surabaya menangani kasus diare sejumlah 50.283 kasus dengan presentase penanganan kasus sebesar $82,49 \%$. Adapun jumlah kasus diare yang ditangani di Jawa Timur sebesar 106,7\%.

Salah satu kelurahan yang ada di Surabaya dengan angka diare yang tergolong tinggi adalah Kelurahan Pegirian. Berdasarkan data yang diperoleh dari Dinas Kesehatan Surabaya tahun 2015 kejadian diare di Kelurahan Pegirian sebanyak 1472 kasus. Tahun 2016, jumlah kasus diare di Kelurahan Pegirian sebanyak 921 kasus. Kasus diare masuk dalam sepuluh penyakit terbanyak di Puskesmas Pegirian dan menempati posisi tertinggi keempat.

Perilaku hidup bersih dan sehat merupakan hasil pembelajaran terhadap perilaku-perilaku yang ditangkap (Destya, 2009). Menurut teori WHO perilaku seseorang dipengaruhi oleh banyak faktor, seperti pemikiran dan perasaan yang dipengaruhi pengetahuan dan sikap seseorang, adanya acuan atau referensi 
dari orang yang dipercayai, sumber daya yang tersedia, serta sosio budaya setempat. Mengintervensi faktor-faktor tersebut dapat menjadi upaya dalam mewujudkan perilaku hidup bersih dan sehat.

Pemerintah telah melakukan berbagai upaya penanggulangan seperti gerakan nasional Sanitasi Total Berbasis Masyarakat (STBM) yang dirancang sejak tahun 2008 dalam rangka mengurangi morbiditas dan mortalitas diare. Program STBM juga dilakukan oleh UNICEF. STBM dilakukan sebagai bagian dari kebijakan pemerintah untuk pengendalian risiko penyakit yang berhubungan dengan lingkungan (Luby, dkk, 2009)

Saat ini, STBM diatur dalam Peraturan Menteri Kesehatan Republik Indonesia Nomor 3 Tahun 2014. Salah satu pilar dalam gerakan ini adalah memakai sabun saat mencuci tangan. Pasal 3 ayat 2 menjelaskan bahwa perilaku Cuci Tangan Pakai Sabun (CPTS) minimal dapat terwujud melalui kegiatan membudayakan perilaku cuci tangan dengan air bersih yang mengalir dan memakai sabun secara berkelanjutan. Sarana cuci tangan yang dilengkapi dengan air mengalir, sabun, dan saluran pembuangan limbah juga harus disediakan dan dipelihara. Gerakan STBM diwujudkan melalui pemberdayaan masyarakat yang dilakukan oleh pemerintah dan bekerjasama dengan lintas sektoral.

Perilaku cuci tangan dapat dipengaruhi oleh beberapa faktor diantaranya yaitu pengetahuan dan sikap (Notoatmodjo, 2010). Pengetahuan merupakan keluaran dari proses sensoris utamanya mata dan telinga terhadap suatu objek tertentu. Sikap merupakan respons tertutup seseorang terhadap objek atau stimulus yang berasal dari dalam maupun dari luar dan manifestasinya tidak dapat dilihat langsung, namun hanya bisa ditafsirkan oleh perilaku yang tertutup tersebut (Sunaryo, 2014). Pengetahuan dan sikap terhadap cuci tangan dapat mempengaruhi seseorang untuk mau dan mampu melakukan perilaku cuci tangan tersebut.

Berdasarkan latar belakang dipaparkan, maka perlu dilakukan penelitian mengenai hubungan antara pengetahuan dan sikap terhadap tindakan cuci tangan yang benar pada masyarakat kelurahan Pegirian.

\section{METODE}

Penelitian ini adalah penelitian kuantitatif dengan rancangan Cross Sectional. Penelitian ini dilakukan di RW III Kelurahan Pegirian Kecamatan Semampir Surabaya pada bulan Januari 2017. Besar populasi dalam penelitian ini sebanyak 536 Kepala Keluarga (KK) dan besar sampel minimal sebanyak 84 responden yang diambil dengan menggunakan simple random sampling. Variabel bebas dalam penelitian ini adalah pengetahuan dan sikap responden tentang cuci tangan yang benar, sedangkan variabel terikat dalam penelitian ini adalah tindakan cuci tangan yang benar.

Pengetahuan diinterpretasikan sebagai pemahaman responden tentang cuci tangan yang benar dengan skala yang bersifat kuantitatif yaitu pengetahuan baik dengan skor $76-100 \%$, pengetahuan cukup dengan skor $56-75 \%$ dan pengetahuan kurang dengan skor kurang dari $56 \%$. Sikap didefinisikan sebagai respons yang akan dilakukan responden tentang cuci tangan yang benar. Sikap diukur menggunakan skala likert yang kemudian diinterpretasikan secara kuantitatif dengan kategori sikap baik dengan skor --100\%, sikap cukup 56-75\% dan sikap kurang dengan skor kurang dari 56\%. Tindakan cuci tangan diinterpretasikan sebagai perlakuan responden dalam melakukan cuci yang benar yang secara kuantitatif dibagi menjadi kategori tindakan baik dengan skor $76-100 \%$, tindakan cukup dengan skor 56-75\% dan tindakan kurang dengan skor kurang dari 56\% (Riwidikdo, 2009)

Data yang digunakan pada penelitian ini yaitu data primer dan data sekunder. Data primer didapatkan dengan bantuan instrumen kuesioner untuk mengukur pengetahuan, sikap, dan tindakan responden tentang cuci tangan yang benar dan data sekunder didapatkan dari data RW III kelurahan Pegirian, data dari balai kelurahan Pegirian, buku, jurnal ilmiah, serta sumber tertulis lain yang mendukung. Data yang terkumpul kemudian dilakukan klasifikasi ulang data, pemberian kode untuk tiap kelompok, kemudian memasukkan data ke dalam sistem SPSS. Data yang telah dimasukkan dilakukkan analisis baik analisis univariat maupun 
J urnal Promkes: The Indonesian J ournal of Health Promotion and Health Education

Vol. 7 No. 1 (2019) 1-11. doi: 10.20473/jpk.V7.I1.2019.1-11

bivariat. Analisis univariat menggunakan analisis deskriptif dengan tujuan untuk mengetahui gambaran serta distribusi frekuensi karakteristik dari masing-masing variabel penelitian, sedangkan analisis bivariat menggunakan analisis korelasi spearman untuk melihat ada hubungan serta kuat hubungan antara variabel bebas dengan variabel terikat. Tiap variabel bebas satu persatu dianalisis untuk mengetahui seberapa kuat hubungan dengan variabel terikat. Nilai uji signifikansi pada penelitian dengan a sebesar 5\%. Hipotesis diterima jika $a \leq 5 \%$ yang berarti ada hubungan, Hipotesis ditolak jika nilai $a \geq 5 \%$ yang berarti tidak ada hubungan.

\section{HASIL DAN PEMBAHASAN}

\section{Gambaran Karakteristik Responden}

Hasil penelitian yang dilakukan terhadap 84 responden, didapatkan data karakteristik responden yang meliputi umur, jenis kelamin, pendidikan, pekerjaan dan penghasilan. Data karakteristik responden dapat dilihat pada tabel 1 di bawah ini:

Berdasarkan hasil penelitian menunjukkan bahwa umur responden yang lebih berisiko mengalami diare adalah umur > 45 dan < 25 tahun. Hal ini karena pada lansia (> 45 tahun) sistem pertahanan tubuh sudah menurun, cara kerja sistem metabolisme dalam tubuh juga menurun sehingga mempengaruhi kekebalan tubuh dan mudah terserang penyakit termasuk diare. Usia anak dan remaja (< 25 tahun) lebih rentan terkena diare karena semakin lama masa hidup seseorang maka semakin banyak pula pengalaman dan pengetahuan untuk menentukan perilaku yang benar dalam menjaga kesehatannya (Suryabudhi, 2003). Berdasarkan hasil penelitian mayoritas responden berusia 25-45 tahun yaitu sebanyak 53 responden (64,2\%). Hal ini menunjukkan bahwa mayoritas responden berada pada usia yang tidak berisiko, namun pengetahuan seseorang belum tentu ditentukan oleh umur orang tersebut. Dari tabel 1 juga terlihat bahwa mayoritas responden juga berada pada usia produktif.

Tabel 1. menunjukkan bahwa persentase responden wanita dan lakilaki hampir sama, yaitu wanita sebanyak 43 orang dan laki-laki sebanyak 41 orang.
Berdasarkan tingkat pendidikan responden dengan tingkat pendidikan SMP dan SMA memiliki persentasi yang hampir sama, yaitu sejumlah 23 orang $(27,3 \%)$ dengan tingkat pendidikan SMP dan 22 orang (25\%) dengan tingkat pendidikan SMA, sementara hanya 6 orang $(7,1 \%)$ responden dengan pendidikan tinggi. Adapun mayoritas responden berpendidikan SD yaitu sejumlah 29 orang $(34,5 \%)$ dan terdapat 5 orang $(5,3 \%)$ responden yang tidak pernah mengenyam bangku pendidikan. Hal ini menunjukkan bahwa banyak masyarakat di RW III kelurahan Pegirian banyak yang berpendidikan rendah. Pekerjaan mayoritas responden bekerja sebagai buruh harian lepas yaitu sebanyak 65 orang $(77,3 \%)$ dan penghasilan per bulan responden masih tergolong rendah. Mayoritas responden mendapatkan penghasilan < 1.000 .000

Tabel 1. Karakteristik responden penelitian

\begin{tabular}{|c|c|c|}
\hline Karakteristik & Frekuensi & $\%$ \\
\hline \multicolumn{3}{|l|}{ Umur } \\
\hline$<25$ & 15 & 17,9 \\
\hline $25-45$ & 53 & 64,2 \\
\hline$>45$ & 15 & 17,9 \\
\hline Total & 84 & 100 \\
\hline \multicolumn{3}{|l|}{ Jenis Kelamin } \\
\hline Laki-laki & 41 & 48,8 \\
\hline Perempuan & 43 & 51,2 \\
\hline Total & 84 & 100 \\
\hline \multicolumn{3}{|l|}{ Pendidikan } \\
\hline Tidak Sekolah & 5 & 5.3 \\
\hline SD/Sederajat & 29 & 34,5 \\
\hline SMP/Sederajat & 23 & 27,3 \\
\hline SMA/Sederajat & 22 & 25 \\
\hline PT & 6 & 7,1 \\
\hline Total & 84 & 100 \\
\hline \multicolumn{3}{|l|}{ Pekerjaan } \\
\hline Pegawai Negeri & 7 & 8,3 \\
\hline Pedagang & 12 & 14,2 \\
\hline $\begin{array}{l}\text { Buruh harian } \\
\text { lepas }\end{array}$ & 65 & 77,3 \\
\hline Total & 84 & 100 \\
\hline \multicolumn{3}{|l|}{ Penghasilan } \\
\hline$<1.000 .000$ & 45 & 53,6 \\
\hline $\begin{array}{l}1.000 .000- \\
3.000 .000\end{array}$ & 33 & 39,3 \\
\hline$>3.000 .000$ & 6 & 7,1 \\
\hline Total & 84 & 100 \\
\hline
\end{tabular}


per bulan yaitu sejumlah 45 responden (53,6\%).

Analisis terhadap data primer yang diperoleh dari 84 responden di RW III Kelurahan Pegirian, menunjukkan bahwa mayoritas penduduk Kelurahan Pegirian berada pada usia produktif. Banyaknya usia produktif dapat menjadi potensi bagi RW III Kelurahan Pegirian. Kelompok masyarakat dengan usia produktif diharapkan dapat meningkatkan status ekonomi masyarakat serta menjadi SDM yang berkualitas untuk kemajuan bangsa khususnya di RW III Kelurahan Pegirian yang diharapkan akan mempengaruhi peningkatan status kesehatan masyarakat itu sendiri.

Proporsi responden dengan jenis kelamin laki-laki dan perempuan hamper sama. Perilaku hidup bersih dan sehat memang menjadi kebutuhan semua orang baik laki-laki maupun perempuan. Termasuk perilaku cuci tangan dengan menggunakan sabun. Perilaku ini perlu diketahui semua orang karena perilaku ini menjadi upaya pencegahan terhadap penyakit.

Data karakteristik pendidikan responden di RW III Kelurahan Pegirian sebagian besar responden menunjukkan tingkat pendidikan yang rendah. Tingkat pendidikan menjadi salah satu karakteristik masyarakat, pada masyarakat dengan tingkat pendidikan yang rendah, hal ini dapat mempengaruhi tingkat kecepatan masyarakat dalam menerima dan memahami informasi yang diberikan, termasuk informasi kesehatan. Tingkat pendidikan juga akan mempengaruhi pola pikir dan persepsi serta wawasan masyarakat. Tingkat pendidikan yang semakin tinggi akan meningkatkan daya tangkap seseorang terhadap informasi. Orang dengan tingkat pendidikan yang lebih tinggi akan lebih mudah menerima dan memahami informasi yang diberikan termasuk mengenai kesehatan.

Mayoritas responden bekerja sebagai buruh harian lepas. Pekerjaan ini membuat penghasilan yang diperoleh masyarakat tidak menentu. Dari data primer yang diperoleh melalui kuesioner, diketahui, mayoritas responden memiliki penghasilan < Rp.1.000.000, angka ini tergolong rendah. Bila dibandingkan dengan upah minimum kabupaten/kota (UMK) Kota Surabaya tahun 2017 yang sebesar Rp.3.296.212,50 maka penghasilan yang diperoleh mayoritas masyarakat RW III Kelurahan Pegirian termasuk kecil. Penghasilan akan mempengaruhi kemampuan masyarakat dalam memenuhi kebutuhan hidupnya. Apabila penghasilan yang diperoleh rendah, masyarakat akan cenderung kesulitan untuk membeli atau memperoleh kebutuhan hidupnya, yang pada akhirnya juga akan mempengaruhi kesehatannya.

Kelurahan Pegirian memiliki potensi yang besar karena banyaknya masyarakat usai produktif yang ada didalamnya. Namun status pendidikan yang tergolong rendah menjadi penghambat dalam memaksimalkan potensi itu. Masyarakat dengan tingkat pendidikan yang rendah cenderung akan sulit mendapatkan pekerjaan yang layak, yang akhirnya akan mempengaruhi penghasilannya. Selain itu pendidikan yang cenderung rendah juga membuat kurangnya mendapatkan informasi kesehatan. Penghasilan yang rendah juga bisa menjadi penghalang bagi masyarakat dalam mengakses layanan atau sarana kesehatan.

Gambaran Pengetahuan, Sikap dan Tindakan Cuci Tangan di RW III Kelurahan Pegirian

Hasil yang diperoleh dari data primer melalui kuesioner yang diberikan pada 84 responden, diperoleh distribusi frekuensi

Tabel 2. Gambaran Pengetahuan, Sikap dan Tindakan Cuci Tangan

\begin{tabular}{lcc}
\hline \multicolumn{1}{c}{$\begin{array}{c}\text { Variabel } \\
\text { Penelitian }\end{array}$} & Frekuensi & (\%) \\
\hline Pengetahuan & & \\
Baik & 4 & 4,8 \\
Cukup & 21 & 25 \\
Kurang & 59 & 70,2 \\
Total & 84 & 100 \\
\hline Sikap & & \\
Baik & 69 & 82,1 \\
Cukup & 14 & 16,7 \\
Kurang & 1 & 1,2 \\
Total & 136 & 100 \\
\hline Tindakan & & \\
Baik & 49 & 58,3 \\
Cukup & 29 & 34,5 \\
Kurang & 6 & 7,1 \\
Total & 84 & 100 \\
\hline
\end{tabular}


pengetahuan, sikap dan tindakan seperti tertera dalam tabel 2 .

\section{Gambaran Pengetahuan Cuci Tangan di RW III Kelurahan Pegirian}

Tabel 2 menunjukkan bahwa hasil mayoritas responden memiliki pengetahuan kurang tentang cuci tangan sebesar 70,2\% atau 59 orang. Berdasarkan batasan operasional penelitian, hal tersebut diartikan bahwa masih banyak responden yang mendapatkan skor nilai pengetahuan $<56 \%$. Hal ini menunjukkan bahwa sebagian besar masyarakat RW III kelurahan Pegirian masih belum memahami tentang cuci tangan, padahal cuci tangan adalah salah satu indikator di dalam perilaku hidup bersih dan sehat yang penting untuk dipahami dan dilakukan. Kurangnya pengetahuan ini bisa jadi dipengaruhi oleh rendahnya tingkat pendidikan masyarakat Kelurahan Pegirian. Mayoritas responden memiliki tingkat pendidikan SD yaitu sebesar $34,5 \%$.

Hasil ini sejalan dengan penelitian yang dilakukan oleh Zuraidah dan Elviani tentang hubungan pengetahuan dan sikap dengan perilaku mencuci tangan yang benar yang mendapatkan hasil hanya $5 \%$ respons dengan yang mengetahui cara mencuci tangan. Sebagian masyarakat mengetahui akan pentingnya mencuci tangan pakai sabun, namun hanya sedikit sekali yang mengetahui bagaimana cara mencuci tangan dengan benar.

Hasil penelitian ini juga sejalan dengan penelitian yang dilakukan oleh Rabbani, dkk tentang Hubungan Pengetahuan Terhadap Perilaku Cuci Tangan Petugas Kesehatan di Bagian Ilmu Kesehatan Anak BLU RSUP Prof Dr RD Kandou Manado. Penelitian Rabbani, dkk diperoleh hasil bahwa mayoritas pengetahuan responden tentang cuci tangan masih kurang baik. Terdapat responden dengan pengetahuan kurang baik yaitu sebesar $70,5 \%$. Hail ini menunjukkan masih banyaknya orang yang belum memahami tentang cuci tangan.

Kesan di dalam pikiran manusia sebagai hasil penggunaan panca indranya menghasilkan pengetahuan (Sukanto, 2005). Pengetahuan adalah output dari tahu. Tahu dapat terjadi apabila terdapat proses pengindraan oleh seseorang melalui panca indranya yang meliputi indra peraba, indra perasa, indra penciuman, indra pendengaran dan indra penglihatan (Notoatmodjo, 2010)

Dasar dilakukannya atau tidak dilakukannya sesuatu bisa berasal dari pengetahuan. Pengetahuan tentang pentingnya cuci tangan serta bagaimana cara mencuci tangan yang benar dengan menggunakan sabun dapat menjadi dasar terhadap dilakukan atau tidak dilakukannya perilaku cuci tangan tersebut oleh seseorang, yang menjadi pondasi atas langgengnya perilaku tersebut.

Hasil penelitian yang dilakukan oleh Syahputri (2011) dikatakan bahwa cuci tangan belum menjadi budaya yang dilakukan oleh masyarakat Indonesia secara luas. Dalam kehidupan sehari-hari masih banyak masyarakat yang mencuci tangan hanya dengan air ketika hendak makan dan cuci tangan dengan sabun dilakukan justru hanya setelah makan, padahal tangan adalah media yang membawa kuman penyakit, sehingga mencucinya sebelum makan menggunakan sabun merupakan upaya pencegahan terhadap penyakit itu sendiri. Mencuci tangan dengan air saja memang lebih umum dilakukan oleh masyarakat namun hal ini terbukti kurang efektif apabila dibandingkan dengan mencuci tangan dengan menggunakan sabun.

\section{Gambaran Sikap terhadap Cuci Tangan di RW III Kelurahan Pegirian}

Tabel 2 mayoritas sikap masyarakat terhadap cuci tangan adalah baik, yaitu sebesar $82,1 \%$ atau sejumlah 69 orang. Sikap merupakan suatu kecenderungan untuk bertindak dan bereaksi terhadap sesuatu baik itu positif maupun negatif. Hasil penelitian didapatkan bahwa sebagian besar masyarakat RW III kelurahan Pegirian sudah memiliki sikap yang positif terhadap perilaku cuci tangan.

Sikap yang diukur terkait cuci tangan pada masyarakat RW III Pegirian ini meliputi tiga komponen, yaitu komponen kognitif, adalah komponen yang berkaitan dengan pandangan dan keyakinan mengenai halhal yang berhubungan dengan bagaimana orang memersepsikan perilaku cuci tangan. Komponen yang kedua adalah komponen afektif, yaitu komponen yang berhubungan dengan bagaimana perasaan 
seseorang, apakah senang atau tidak senang dengan perilaku cuci tangan. Rasa senang merupakan hal yang positif, sementara rasa tidak senang merupakan hal yang negatif, aspek emosional ini menunjukkan arah sikap seseorang yaitu positif atau negatif. Komponen yang ketiga yaitu komponen konatif, adalah komponen yang berhubungan dengan kecenderungan bertindak untuk melakukan perilaku cuci tangan. Komponen ini menunjukkan besar kecilnya kecenderungan responden untuk berperilaku cuci tangan.

Sikap menjadi faktor predisposisi untuk melakukan atau tidak melakukan suatu perilaku tertentu, sikap menjadi proses kesadaran yang sifatnya individual. Hal ini berarti proses ini terjadi pada diri individu secara subjektif dan unik (Wawan, 2010). Sikap masyarakat terhadap cuci tangan bisa mempengaruhi dilakukan atau tidak dilakukannya perilaku cuci tangan oleh masyarakat tersebut. Semakin positif sikap seseorang maka semakin besar kemungkinan timbulnya tindakan tersebut.

Secara garis besar sikap masyarakat RW III Kelurahan Pegirian sudah tergolong baik, hal ini akan memicu timbulnya tindakan atau dilakukannya perilaku cuci tangan. Cuci tangan menjadi salah satu cara untuk mencegah timbulnya penyakit, melalui sikap yang baik diharapkan kejadian kesakitan yang terjadi di masyarakat bisa menurun.

\section{Gambaran Tindakan terhadap Cuci Tangan di RW III Kelurahan Pegirian}

Penelitian yang dilakukan terhadap 84 responden, diperoleh hasil bahwa lebih dari separuh responden memiliki tindakan yang baik terhadap cuci tangan yaitu sebesar $58,3 \%$ atau sejumlah 49 orang, disusul dengan kategori tindakan cuci tangan cukup sebesar 34,5\% atau sejumlah 29 orang.

Penelitian yang dilakukan oleh Kusumawardhani, dkk tentang pengetahuan, sikap, dan tindakan mencuci tangan yang benar pada siswa kelas 1 dan 2 di SDN 2 Karanglo, Klaten Selatan, mayoritas responden juga memiliki tindakan yang baik. Terdapat $97 \%$ responden dengan tindakan cuci tangan yang baik.

Hasil penelitian ini diperoleh bahwa mayoritas responden sudah mempunyai kebiasaan melakukan cuci tangan, misalnya sebelum makan, setelah buang air besar, setelah memegang hewan peliharaan, namun hal yang masih kurang adalah tindakan cuci tangan ini belum sesuai dengan cara cuci tangan yang baik dan benar. Penggunaan sabun dan air yang mengalir serta mencuci tangan sesuai langkah-langkah yang benar belum banyak dilakukan.

Tindakan merupakan respons individu terhadap suatu stimulus. Pengetahuan dan sikap bisa menjadi stimulus yang meningkatkan kemungkinan dilakukannya sebuah tindakan. Semakin baik pengetahuan individu terhadap sesuatu semakin meningkat pula kemungkinan dilakukannya perilaku tersebut. Begitupula dengan sikap, semakin baik sikap seseorang terhadap sesuatu, maka semakin meningkat pula kemungkinan dilakukannya sebuah perilaku.

Tindakan cuci tangan yang dilakukan responden bisa dipengaruhi oleh pengetahuan tentang cuci tangan maupun sikap responden terhadap cuci tangan tersebut, namun sikap yang baik tanpa didasari pengetahuan yang baik dapat menghasilkan tindakan yang salah.

\section{Hubungan Pengetahuan dan Sikap terhadap Tindakan Cuci Tangan}

Setelah distribusi frekuensi diketahui selanjutnya dilakukan uji korelasi spearman untuk mengetahui hubungan antara variabel bebas dan variabel terikat. Hasil uji Korelasi spearman antara variabel bebas (pengetahuan dan sikap) dengan variabel terikat (tindakan) adalah sebagaimana dalam Tabel 3.

\section{Hubungan Pengetahuan Dengan Tindakan Cuci Tangan}

Hasil pada tabel 3 menunjukkan bahwa terdapat hubungan antara pengetahuan dengan tindakan cuci tangan yaitu dengan hasil $p$ value sebesar 0,009 karena menujukan nilai signifikansi kurang dari 0,05 (sig<0,0,5). Kuat hubungan bersifat kuat dikarenakan hasil dari koefisien korelasinya sebesar 0,282. Nilai koefisien korelasi berada dalam kisaran -1 sampai 1 . Kuat hubungan semakin kuat apabila angka koefisien korelasi semakin mendekati nol.

Hasil ini sejalan dengan penelitian yang dilakukan Zuraidah dan Elviani (2016) yaitu 
Tabel 3. Hubungan Pengetahuan dan Sikap Dengan Tindakan Cuci Tangan

\begin{tabular}{lll}
\hline & $\begin{array}{l}\text { Koefisien } \\
\text { korelasi }\end{array}$ & P Value \\
\hline $\begin{array}{l}\text { Hubungan } \\
\text { pengetahuan } \\
\text { dengan tindakan } \\
\text { cuci tangan }\end{array}$ & 0,282 & 0,009 \\
\hline $\begin{array}{l}\text { Hubungan sikap } \\
\text { dengan tindakan } \\
\text { cuci tangan }\end{array}$ & 0,271 & 0,013 \\
\hline
\end{tabular}

terdapat hubungan antara pengetahuan terhadap tindakan cuci tangan dengan $\mathrm{p}$ value 0,029 .

Penelitian yang dilakukan oleh Jeliantik dan Astarini (2014) tentang hubungan pengetahuan dan tindakan cuci tangan, juga memperoleh hasil yang serupa, terdapat hubungan antara pengetahuan dan tindakan cuci tangan dengan nilai $p$ value 0,000 .

Hasil uji univariate pada penelitian ini diperoleh bahwa mayoritas responden memiliki pengetahuan kurang yaitu sebesar $70,2 \%$, sementara pada variabel tindakan, mayoritas responden memiliki tindakan yang baik yaitu sebesar 58,3\%. Hal ini karena masyarakat Kelurahan Pegirian sebenarnya sudah memiliki kebiasaan mencuci tangan, sehingga pada variabel tindakan, mayoritas responden sudah memiliki tindakan yang baik. Masyarakat Kelurahan Pegirian mengaku sudah melakukan tindakan cuci tangan pada waktu-waktu mencuci tangan diantaranya sebelum makan, setelah buang air besar, setelah memegang hewan peliharaan, namun tindakan ini belum ditunjang oleh pengetahuan yang baik tentang cara cuci tangan yang benar. Banyak masyarakat yang belum tahu tentang langkah-langkah mencuci tangan yang benar dan belum menggunakan sabun dalam keseharian mereka mencuci tangan.

Meskipun demikian, berdasarkan uji bivariat diperoleh nilai $p$ value 0,009 yang berarti terdapat hubungan antara pengetahuan terhadap tindakan cuci tangan pada masyarakat Kelurahan Pegirian. Hal ini karena responden dengan pengetahuan cukup memiliki tindakan yang cukup, serta pada responden dengan pengetahuan baik ternyata memiliki tindakan yang baik pula, sehingga saat dilakukan uji korelasi menggunakan spearman didapatkan hasil $p$ value < 0,05 yang artinya terdapat hubungan antara pengetahuan terhadap tindakan cuci tangan.

Perilaku cuci tangan pada umumnya sudah diperkenalkan sejak anak-anak, bahkan hal ini menjadi kegiatan rutin di sekolah. Kenyataannya perilaku sehat ini belum menjadi budaya masyarakat kita dan biasanya hanya dilakukan sekedarnya saja. Masyarakat pada umumnya hanya menggunakan air seadanya dan belum banyak menggunakan sabun untuk cuci tangan (Depkes, 2011)

Mencuci tangan dengan sabun dapat memangkas angka penderita diare hingga separuh. Penyakit diare seringkali dikaitkan dengan kondisi air, tapi hal lain yang seharusnya juga menjadi perhatian adalah penanganan kotoran manusia seperti air kencing atau tinja, hal ini karena kumankuman penyakit yang menyebabkan diare berasal dari kuman-kuman yang ada pada kotoran ini. Kuman ini dapat menyebabkan manusia menjadi sakit karena kumankuman ini masuk melalui tangan setelah menyentuh kotoran, air minum yang terkontaminasi, makanan mentah yang terkontaminasi, serta peralatan makanan yang terkontaminasi dan tidak dicuci dengan bersih. Mencuci tangan yang benar dengan menggunakan sabun memiliki tingkat keefektifan sebesar 44\% terhadap penurunan angka diare (Kemenkes, 2013).

Riset menunjukkan bahwa penyebab terbesar meninggalnya balita dan anak-anak di Indonesia dikarenakan penyakit diare dan ISPA. Saat ini, pemahaman serta kepedulian dalam mempromosikan praktik cuci tangan yang benar perlu untuk semakin ditingkatkan. Masih dibutuhkan usaha-usaha untuk meningkatkan kepedulian masyarakat terhadap dampak positif yang akan muncul dari cuci tangan menggunakan sabun dengan menggandeng kantor-kantor pemerintah, pihak swasta maupun LSM untuk bersama-sama mempromosikan seruan dan ajakan mencuci tangan pakai sabun sebagai aktivitas bagi semua lapisan masyarakat (Depkes RI, 2011).

Pengetahuan merupakan faktor yang sangat penting yang bisa memicu terjadinya perilaku yang benar dan membuat perilaku tersebut bersifat langgeng (Sukanto, 2005). Penelitian ini sehubungan masih banyaknya 
masyarakat yang belum mengetahui cara cuci tangan yang benar, maka perlu ditingkatkan upaya promosi kesehatan tentang cuci tangan pada masyarakat Kelurahan Pegirian. Hal ini sebagai upaya untuk memperbaiki perilaku hidup bersih dan sehat di masyarakat.

\section{Hubungan Sikap dengan Tindakan Cuci Tangan}

Tabel 3 menunjukkan hasil analisis korelasi spearman dengan nilai signifikan $\mathrm{p}=0.013$ (sig $<0,05$ ) yang berarti terdapat hubungan antara sikap dengan tindakan cuci tangan. Kuat hubungan pengetahuan dengan tindakan cuci tangan menunjukkan hasil 0,275 yang berarti hubungan bersifat kuat. Nilai koefisien korelasi berada dalam kisaran -1 sampai 1. Kuat hubungan semakin kuat apabila angka koefisien korelasi semakin mendekati nol. Hal ini berarti orang yang memiliki sikap yang baik terhadap cuci tangan cenderung memiliki tindakan cuci tangan yang baik.

Hasil penelitian ini sejalan dengan penelitian yang dilakukan oleh Jelantik dan Astarini (2014) yang memperoleh hasil p value 0,009 yang artinya terdapat hubungan antara sikap dengan tindakan cuci tangan.

Hasil uji univariat diperoleh bahwa mayoritas responden memiliki sikap yang baik yaitu sebesar 82,1\% dan mayoritas responden juga memiliki tindakan yang baik yaitu sebesar 58,3\%. Hal ini menunjukkan kesesuaian bahwa sikap yang baik akan mempengaruhi tindakan yang baik. Mayoritas masyarakat sudah menyetujui bahwa cuci tangan adalah hal yang penting untuk dilakukan.

Sikap merupakan reaksi atau respons (penilaian) yang sifatnya masih tertutup oleh seseorang yang mempengaruhi kecenderungan orang tersebut untuk melakukan atau tidak melakukan sebuah perilaku. Tindakan adalah suatu respons seseorang terhadap stimulus, apabila sikap terhadap suatu perilaku bersifat positif maka kecenderungan tindakan untuk melakukan hal tersebut akan meningkat (Wawan, 2010)

Sikap terhadap mencuci tangan yang positif akan memicu dilakukannya tindakan cuci tangan. Mayoritas masyarakat Kelurahan Pegirian sudah memiliki sikap yang positif terhadap cuci tangan. Banyak masyarakat yang sudah menganggap bahwa cuci tangan sebagai hal yang penting, namun hal yang masih kurang pada masyarakat Kelurahan Pegirian adalah belum benarnya cara melakukan cuci tangan. Hal tersebut karena masih rendahnya pengetahuan masyarakat Pegirian mengenai cara cuci tangan, sehingga tindakan cuci tangan yang dilakukan belum sepenuhnya benar. Masyarakat hanya mencuci tangan sekedarnya.

Cuci tangan yang benar belum menjadi kebiasaan ataupun budaya yang dilakukan seluruh masyarakat. (Aditama, 2011). Fasilitas cuci tangan sudah sangat memenuhi syarat di beberapa tempat yaitu sudah tersedianya air bersih yang mengalir dan tersedianya sabun cuci tangan, namun fasilitas ini belum digunakan dengan baik. Kebiasaan orang dalam mencuci tangan hanya sekedar menghilangkan bau amis setelah makan, malas atau lupa untuk menggunakan sabun atau bahkan tidak mencuci tangan sebelum makan (Depkes, 2011).

Hal tersebut juga terjadi pada masyarakat Kelurahan Pegirian. Warga sudah memiliki akses air bersih dan mempunyai sabun yang dapat digunakan untuk mencuci tangan, namun dalam kenyataannya perilaku mencuci tangan yang dilakukan belum sesuai dengan langkah yang seharusnya. Risiko terkena penyakit seperti diare masih rentan dihadapi masyarakat karena pengetahuan yang masih kurang meskipun sikap masyarakat terhadap kebiasaan mencuci tangan sudah baik.

Beberapa hal di atas menunjukkan kenyataan bahwa masyarakat masih belum memahami perilaku mencuci tangan menggunakan sabun yang merupakan salah satu upaya kebersihan diri. Sikap serta praktiknya pun masih belum banyak diterapkan oleh masyarakat dalam kehidupan sehari-hari, padahal tindakan cuci tangan yang benar merupakan suatu perilaku yang berdampak positif bagi kesehatan.

Oleh karenanya menimbulkan kesadaran dan kebiasaan mencuci tangan yang benar di masyarakat adalah hal yang penting, agar satu sama lain manusia tidak saling menularkan penyakit. 


\section{SIMPULAN}

Berdasarkan hasil penelitian yang telah dilakukan di RW III Kelurahan Pegirian Kecamatan Semampir Surabaya, maka kesimpulan yang dapat ditarik oleh peneliti adalah sebagai berikut:

a. Terdapat hubungan antara pengetahuan dengan tindakan cuci tangan dan kuat hubungan bersifat kuat

b. Terdapat hubungan antara sikap dengan tindakan cuci tangan dan kuat hubungan bersifat kuat.

\section{DAFTAR PUSTAKA}

Aditya, S.D. 2008. Metodelogi research Variabel Penelitian dan Definisi Operasional. Tersedia di: https:// adityasetyawan.files.wordpress. com/2009/01/variable-penelitian-dandefinisi-operasional-variable2.pdf [25 November 2017].

Anggrainy R. 2010. Cuci Tangan Pakai Sabun Untuk Menurunkan Angka Diare Di Daerah Istimewa Yogyakarta Dalam Program Mendukung Perilaku Hidup Bersih. Tersedia di: http:// www. perilakuhidupbersih(PHBS).com [20 November 2017].

Badan Penelitian dan Pengembangan Kesehatan Kementerian Kesehatan RI. 2013. Riset Kesehatan Dasar (Riskesdas) 2013. Jakarta: Kementerian Kesehatan Republik Indonesia.

Burton, M., Cobb, E., Donachie, P., Judah, G., Curtis, V \& Schmidit, W. 2011. The effect of handwashing with water or soap on bacterial contamination of hands. Int. J. Environ. Res. Public Health, 8 , pp.97-104.

Dahlan dan Umrah. 2013. Buku ajaran ketrampilan dasar praktik kebidanan. Malang: Intimedia.

Depkes RI. 2007. Pedoman Teknis Penilaian Rumah Sehat. Jakarta: Direktorat Jenderal Pengendalian Penyakit dan Penyehatan lingkungan. . 2016. Profil Kesehatan Indonesia 2016. Jakarta: Departemen Kesehatan Republik Indonesia. . 2008. Panduan Manajemen PHBS Menuju Kabupaten/Kota Sehat. Departemen Kesehatan RI: Jakarta. . 2011. Buku Saku Diare Edisi 2011. Jakarta: Departemen Kesehatan RI.
Destya. 2009. Faktor-Faktor Yang Berhubungan Dengan Motivasi Keluarga Untuk Melakukan PHBS. Tersedia di http: / /ctd.eprints.ums.ac.id/6436/l/ J210050091.pdf. [06 Desember 2017].

Dinkes Provinsi Jawa Timur. 2015.Profil Kesehatan Jawa Timur. Surabaya: Dinas Kesehatan Provinsi Jawa Timur.

Kementerian Kesehatan RI. 2017.Profil Kesehatan Indonesia. Jakarta: Kementerian Kesehatan RI.

Luby, S.P., Agboatwalla, M., Bowen, A., Kenah, E., Sharker, Y \& Hoekstra, R.M. 2009. Difficulties in Maintaining Improved Handwashing Behavior, Karachi, Pakistan. Am. J. Trop. Med. Hyg, 81(1), pp.140-145.

Maulana, H. D. J., 2007. Promosi Kesehatan. Jakarta: KGC.

Muslimah. 2010. Gizi dan Pola Hidup Sehat. Yrama Widya: Bandung.

Notoatmodjo, S. 2010. Ilmu Perilaku Kesehatan. Jakarta: PT Rineka Cipta 2010. Metodologi Penelitian Kesehatan. Jakarta: PT Rineka Cipta.

Paramita A, Sopacua E, Widjiartini. 2011. Hubungan Akses Air Bersih Dengan Perilaku Cuci Tangan Pakai Sabun Pada Rumah Tangga Yang Mempunyai Balita Di Indonesia. Jurnal Manajemen Pelayanan Kesehatan. [e-journal] 14(01): pp.28-35. Tersedia di; https: / / journal.ugm.ac.id/ jmpk/article/view/2584/2316 [diakses tanggal 2 januari 2018].

Peraturan Menteri Kesehatan Nomor 3 Tahun 2014 Tentang Sanitasi Total Berbasis Masyarakat. Jakarta: Menteri Kesehatan Republik Indonesia.

Riwidikdo. 2008. Metodelogi Penelitian Kesehatan. Jakarta: Bina Pustaka

Saryono. 2008. Metodologi Penelitian Kesehatan Penuntun Praktis Bagi Pemula. Jogjakarta: Mitra Cendikia Press.

Sitorus, Nikson dan Luci F. 2014. Pengaruh Pendidikan Kesehatan Terhadap Pengetahuan dan Sikap Cuci Tangan pakai Sabun pada Siswa SD Negeri 157 Kota Palembang Tahun 2014. Jurnal Poltekkes Kemenkes Palembang Jurusan Keperawatan. Tersedia di: $<$ jurnal.poltekkespalembang.ac.id/ wp.../04/14-jurnal-Nikson-sitorus.pdf> [03 Desember 2017].

Sunaryo. 2014. Psikologi Untuk Keperawatan. Jakarta: EGC. 
Suryabudhi, M.2003. Cara Merawat Bayi dan Anak-Anak. Bandung: Alfabeta.

Syahputri. 2011. Hubungan Perilaku Hidup Bersih dan Sehat Dengan Kejadian Diare Pada Balita Usia 1-3 tahun. Tersedia di <http://www.perilaku hidup bersih (PHBS).com> [2 Desember 2017]

Sulistyowati, D. 2012. Pengaruh Intervensi Promosi Kesehatan terhadap Pengetahuan, Sikap, dan Praktik Cuci Tangan Pakai Sabun Pada Siswa kelas 5 di SD Pengasinan IV Kota Bekasi Tahun 2012. Skripsi. Universitas Indonesia. Tersedia di $<$ lib.ui.ac.id / file?file=digital /20320736S-PDF-Dewi\%20Listyowati.pdf> [28 November 2017]

Utami W. 2010. Faktor-Faktor Yang Berhubungan Dengan Kebiasaan Cuci Tangan Pakai Sabun Pada Masyarakat Di Cikoneng Kecamatan Ganeas
Kabupaten Sumedang Tahun 2010. Thesis. Tersedia di: <https://www.scribd.com> [12 januari 2018]

Widjaja. 2002. Mengatasi Diare dan Keracunan Pada Balita. Jakarta: Kawan Pustaka

WHO. (2009). WHO guidelines on hand hygiene in health care first global patient safety challenge. Switzerland: WHO Press.

Zuraidah dan Elviani. 2013. Hubungan Pengetahuan Dan Sikap Dengan Perilaku Mencuci Tangan Dengan Benar Pada Siswa Kelas V SDIT AN-NIDA' Kota Lubuklinggau Tahun 2013. Fakultas Keperawatan. Politeknik Kesehatan Palembang. Tersedia di: <https:// www.scribd.com/doc/266736927/ Hubungan-Pengetahuan-Dan-SikapDengan-Perilaku> [3 Januari 2018] 